The coloration may be brown or very dark brown with a lighter mid-dorsal stripe down the back and two darker lines along its border on each side. There are three prominent light yellowish triangular spots on the neck. (I am unable to see them in my specimen). The belly is some shade of red; the chin is white.

The range of the Northern Redbelly Snake is reported to be from eastern U.S.A. to southern Canada west to the 100th meridian. In Saskatchewan it is found in the Qu'Appelle River valley. Gerald is within the known range.

This is the second time I have seen the species in this area. Many years ago I came across a live one. Today's specimen ended in my collection.

BRIMLEY, C.S. The amphibians and reptiles of North Carolina. Raleigh, N.C. Carolina Tips (32 installments, 1939-1943).

COOK, Francis R. 1977. A guide to the amphibians and reptiles of Saskatchewan. Sask. Mus. of Nat. Hist. Pop. Ser. No.13. 40 pp.

\title{
SIGHTING OF LEWIS' WOODPECKER NEAR LEBRET, SASKATCHEWAN
}

FRANK H. BRAZIER, 2657 Cameron Street, Regina, Saskatchewan. S4T 2W5

On 17 June 1972, in bright sunshine at about 5 p.m., Manley Callin and I were approaching the (then) Skinner Farm in the Qu'Appelle River valley, east of Lebret. We had stopped at a road cutting about $0.5 \mathrm{mi}$. west of the farm to examine a colony of Bank Swallows, hoping to find Northern Rough-winged Swallows. Suddenly I saw a dark, flicker-sized woodpecker flying fairly low with unhurried flaps from east to west along the edge of the trees about 100 feet away; it then swung southwesterly across a field before disappearing into the poplar woods.

As soon as I saw it, I knew at once it was a Lewis' Woodpecker as I had seen many of them in British Columbia a few years previously. Once seen, its characteristic flight and appearance in flight is never forgotten. Although when viewed at close range the dark red face and belly, gray collar and breast and dark green back can be readily seen, in flight it appears to be all black. It could be confused with a small crow except for its slightly undulating flight, which is much less so than that of other woodpeckers. It could not have been a Northern Flicker as no white appeared at all and no golden wing linings were seen. Actually, about a minute later a flicker did come by on the same course. There was no doubt about its identity, nor have I any doubt about the identity of the Lewis' Woodpecker. There are three previous records for the Regina area. ${ }^{1}$

When the bird appeared I was a few feet ahead of Manley. I shouted "Look, a Lewis' Woodpecker!" and kept my eyes on it until it was gone. When I turned around, I found that Manley had looked in the wrong direction so did not see it. I crossed the field to search but could not find the bird.

\section{Epilogue}

It was the late Manley Callin's unfailing task after arriving home to write up accounts and list the birds seen during our trips, so l expected he would have noted my sighting of the Lewis' Woodpecker. When I returned to Regina I wrote an account for my own records. Years later, 
in 1978 and 1979, when I often went to Fort Qu'Appelle to help him checking his MS of Birds of the Qu'Appelle (18571979) (SNHS Special Publication No.13), I inquired about the absence of the sighting in his account of the occurrences of Lewis' Woodpecker. He did not remember the incident nor, when he searched his records, could he find a reference. At home I looked for the account I recalled writing but to no avail - it had disappeared. Birds of the Qu'Appelle (1857-1979) was published without it.
Recently I discovered the account I had written on 17 June 1972. The details appear above. I offer this as an amendment to HOUSTON, C. STUART and MARY I. HOUSTON. Additions to Callin's Birds of the Qu'Appelle. Blue Jay $44: 70-84$.

${ }^{1}$ BELCHER, Margaret. 1980. Birds of Regina. Spec. Pub. No.12, Sask. Nat. Hist. Soc. 151 pp.

\section{TWO RUFFED GROUSE ENCOUNTERS}

JIM A. WEDGWOOD, 610 Leslie Avenue, Saskatoon, Saskatchewan. S7H 2 Z2

\section{Another "Crazy-flight"}

In the morning on 4 September 1988, Ken Giesbrecht noticed from his cottage window at Big Shell Lake a stray cat stalking a covey of 10 Ruffed Grouse. Some birds were on the ground, others were in trees, all watching the cat. Then in ones, twos and threes, the grouse flushed, rocketing through the poplars toward the adjacent lot where, except for three birds, they veered around and over a shed. The three, however, in quick succession crashed fatally into a window on the shed.

Ken concluded the birds were immatures. Upon dressing the carcasses, he found the skin over the keel split readily, whereas he finds it tough on older grouse. He remarked that both shanks of the wishbone (furcula) on each bird were broken.

The small $91 \times 45 \mathrm{~cm}(36 \times 18$ in.) window struck by the birds was the middle one of a set of three placed high in the wall under a protruding roof. With no windows in the opposite wall of the unlit shed, a bird should not have been miscued by a view through the building; there might have been, however, a reflected image of the trees behind them.

Ken believed the two followers may have been acting as did two pilots in the recent tragedy of a three-member aerobatics team. There the leader misjudged, flew into the ground, and the other two followed him. Opinion was that the following pilots had concentrated on keeping station to the exclusion of all else.

The phenomenon of Ruffed Grouse occasionally flying wildly about and often hitting objects, including windows, has been termed "crazy-flight."2 Implying knowledge of the trait was the old-timer who years ago cautioned me to board up our cottage windows in the fall, "to stop the stupid grouse from breaking the glass." In articles in Blue Jay, Victor Friesen reviewed the literature on the subject and noted that 16 theories had been advanced to explain crazy-flights. ${ }^{23}$ Regardless of cause, and recognizing that others of the covey had already dodged the shed, crazy-flight behaviour would seem to fit the actions of the lead bird in the Shell Lake instance. 